\title{
Water-use Trends and Distribution in the United States, 1950-85
}

\author{
Wayne B. Solley \\ U.S. Geological Survey, Reston, VA 22092
}

\begin{abstract}
Water use in the United States increased from 1950 to 1980 and decreased from 1980 to 1985 according to estimates compiled at 5year intervals by the U.S. Geological Survey. These estimates are based on information collected by state and local agencies. Total freshwater and saline water withdrawals in the United States during 1985 were 1510 million $\mathrm{m}^{3} \cdot$ day $^{-1}$ (Solley et al., 1988), a rate more than double that estimated for 1950 (Fig. 1) and 10\% less than that estimated for 1980. For most categories, the rate of increase in water use (self-supplied withdrawals and public-supply deliveries) declined from 1970 to 1975 and from 1975 to 1980 . Withdrawals for thermoelectric-power generation and irrigation, the two largest use categories, were $13 \%$ and $6 \%$ less, respectively, during 1985 than during 1980. The combined total for industrial, commercial, and mining water use was $25 \%$ less during 1985 than during 1980. The 1985 total was the lowest combined estimate for these categories since the compilations began in 1950. The decrease in water use in 1985 compared to that in 1980 was the result of $10 \%$ and $12 \%$ less surface and groundwater withdrawals, respectively. The declines were widespread, as 37 states reported less water withdrawn during 1985 than during 1980.
\end{abstract}

The declines can be attributed to four important factors.

1) Water availability, especially precipitation and streamflow, in a particular year strongly affects the quantity of water used for irrigation. Stream flow generally was more plentiful in 1985 than in 1980 because of more rainfall; this reduced the dependence on groundwater in many areas and the need to irrigate in some areas.

2) New technologies that require less water, improved plant efficiency, increased water recycling, higher energy prices, and laws and regulations to reduce pollutant discharge decreased industrial water use and the amount of water returned to the natural system after use.

3) Higher energy prices, improved application techniques, increased competition for water, declines in farm commodity prices, and a downturn in farm economy in the early 1980s reduced demands for irrigation water.

4) Enhanced public awareness of water resources and active conservation programs in many states have reduced water demands.

For a better understanding of how water is used, water use is subdivided into categories, and, in this paper, the United States is subdivided into regions to analyze regional trends. The "West" includes North Dakota, South Dakota, Nebraska, Kansas, Oklahoma, Texas, and states to their west. The "East" is subdivided into the "Northeast" and "Southeast," with Kentucky and Virginia included in the Southeast.

\section{Domestic water use}

Domestic water use (self-supplied withdrawals and public-supply deliveries) nationwide increased $\approx 75 \%$ from 1960 (60 million $\mathrm{m}^{3} \cdot$ day $\left.^{-1}\right)$ to $1985\left(105\right.$ million $\mathrm{m}^{3} \cdot$ day $\left.^{-1}\right)$ (Fig. 2). During the same period, population increased $\approx 33 \%$. All three U.S. regions showed

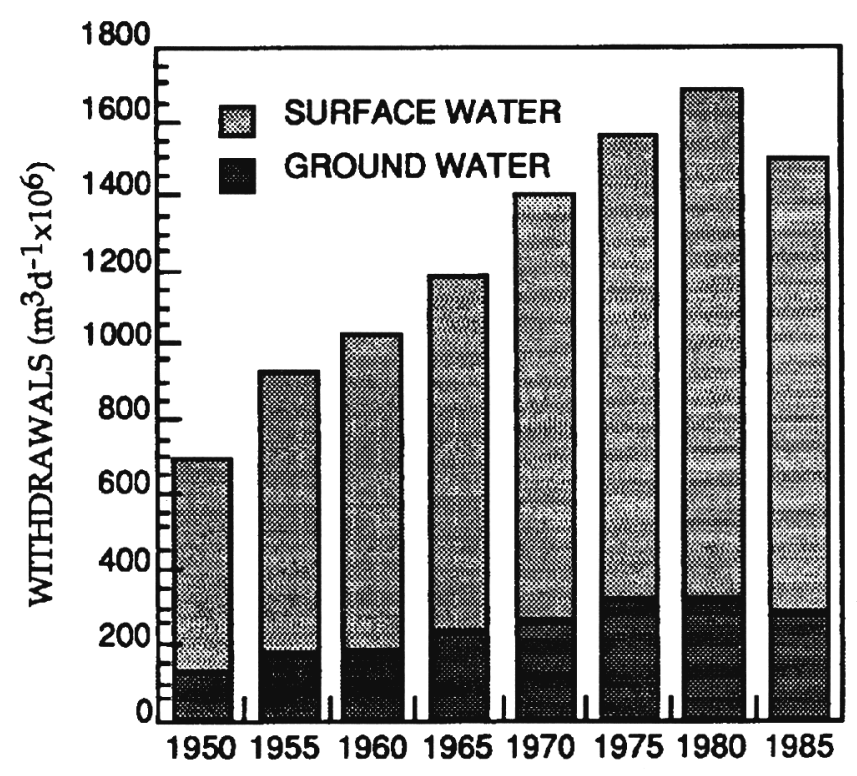

Fig. 1. Trends in U.S. surface and groundwater withdrawals, 1950-85. 
fairly steady increases in domestic use. Domestic per-capita use increased from $\approx 0.34 \mathrm{~m}^{3} \cdot$ day $^{-1}$ during 1960 to $0.44 \mathrm{~m}^{3} \cdot$ day during 1985 and was the highest in the West. Per-capita use averaged 0.57 $\mathrm{m}^{3} \cdot$ day $^{-1}$ in the West during $1985,0.40 \mathrm{~m}^{3} \cdot$ day $^{-1}$ in the Southeast, and $0.42 \mathrm{~m}^{3} \cdot$ day $^{-1}$ in the Northeast. For the population served by its own water systems, 1985 domestic withdrawals nationwide averaged $\approx 0.30$ $\mathrm{m}^{3} \cdot$ day $^{-1}$ per capita, about the same average as during 1980 .

\section{Irrigation water use}

Water withdrawals for irrigation increased from $\approx 337$ million $\mathrm{m}^{3} \cdot$ day $^{-1}$ during 1950 to 549 million $\mathrm{m}^{3} \cdot$ day $^{-1}$ during 1980 (Fig. 3). Withdrawals for 1985 reversed the trend and were 519 million $\mathrm{m}^{3} \cdot$ day $^{-1}$ $6 \%$ less than the 1980 estimate. The reduction was mainly in groundwater withdrawals in the West and East.

The rate of increase in the number of hectares irrigated has been decreasing since 1970. Irrigated hectares in the West increased from 15 million during 1960 to 20 million during 1980, and decreased to 19 million during 1985. In the East, the number of irrigated hectares increased from 1.4 million in 1960 to 3.9 million in 1985 .

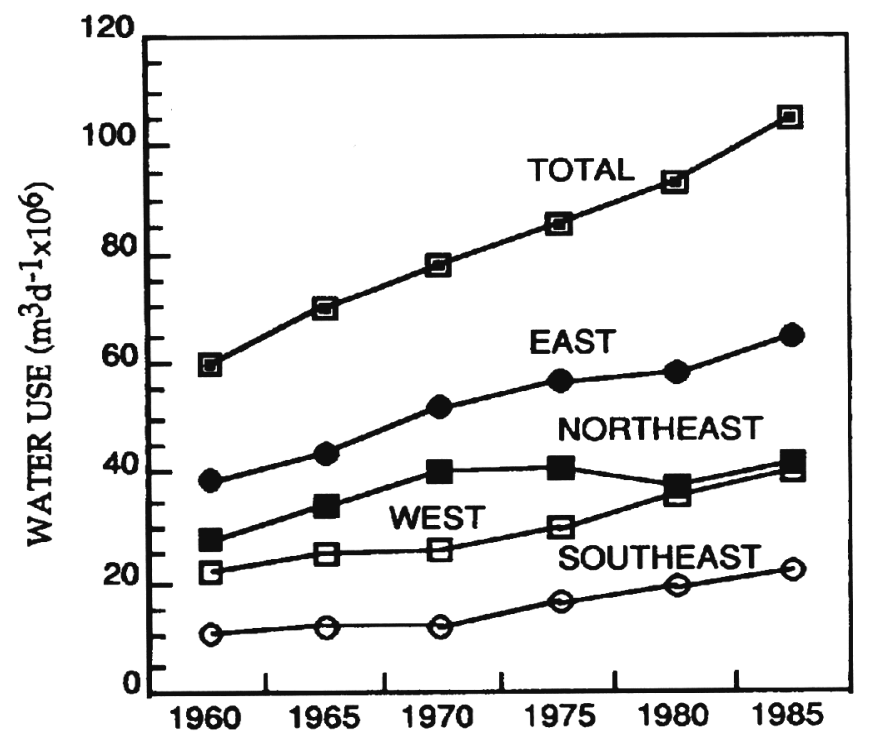

Fig. 2. Trends in regional domestic water use, 1960-85.

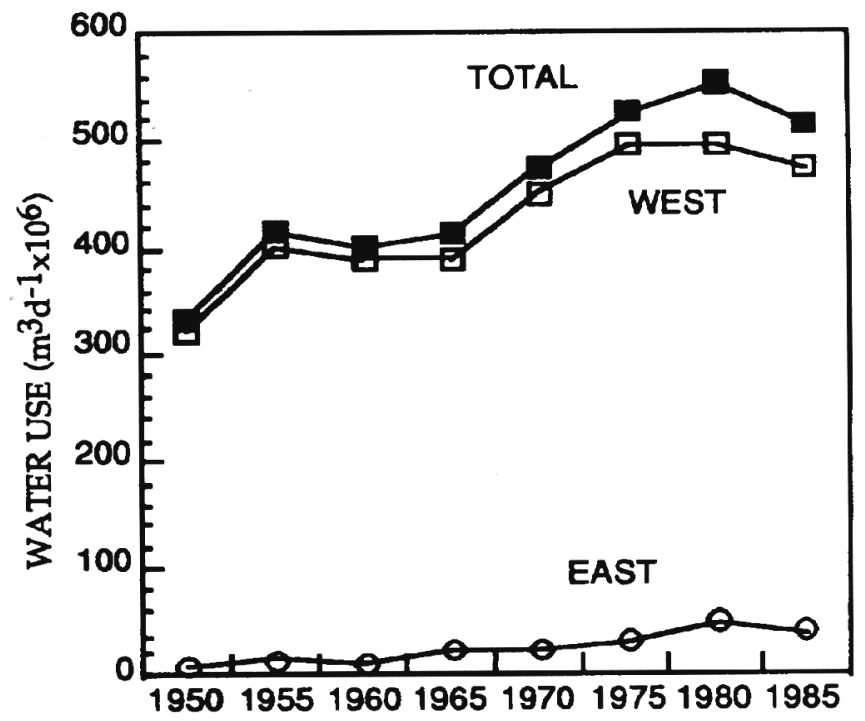

Fig. 3. Trends in regional irrigation water use, 1950-85.
In an informal survey of major irrigation states in the West and of Florida, I found that the amount of irrigation used to produce horticultural crops varied greatly, as did the definition of horticultural crops. The Bureau of the Census (BOC) defines horticultural crops as ornamental floriculture, nursery products, and food crops grown under cover. Based on the BOC definition, California's horticultural water use is only $\approx 0.3 \%$ of total irrigation. When based on the Society's definition, however, it is $\approx 33 \%$ of total irrigation.

Using the ASHS definition, Colorado, Montana, and Wyoming reported that $<1 \%$ of irrigation was used to produce horticultural crops, while Oregon reported 11\%, and Arizona reported 19\%. Idaho reported that potatoes accounted for $>80 \%$ of total crops produced but did not list irrigation statistics by crop. In Florida, $\approx 77 \%$ of irrigation is used for horticultural crops, which are dominated by fruit crops.

\section{Thermoelectric-power water use}

More water continues to be withdrawn for thermoelectric-power generation than for any other category, even though less water was withdrawn for this purpose during 1985 than during 1980 (719 vs. 795

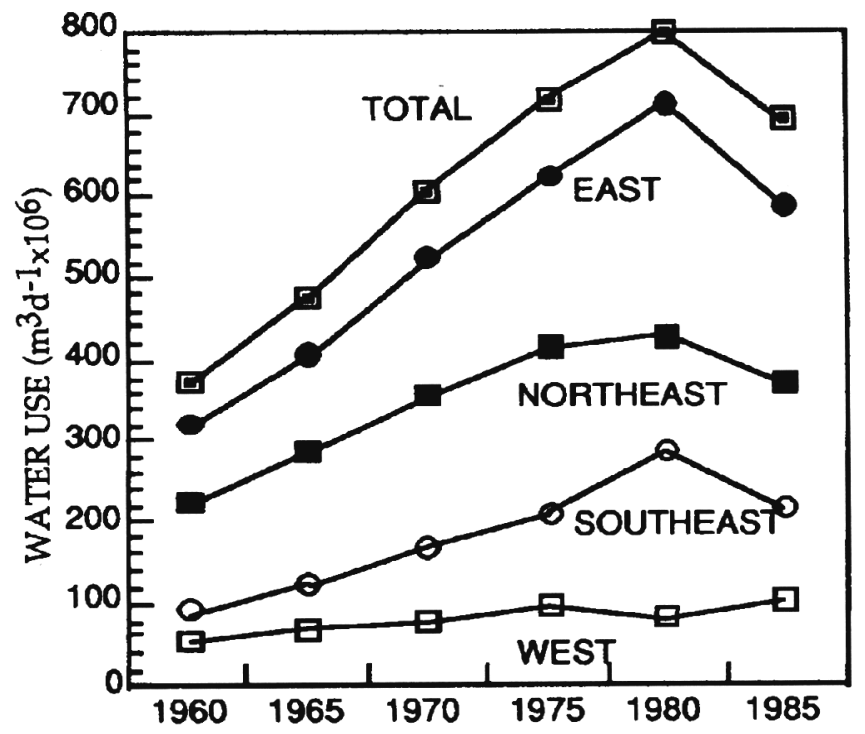

Fig. 4. Trends in regional thermoelectric-power water use, 1960-85.

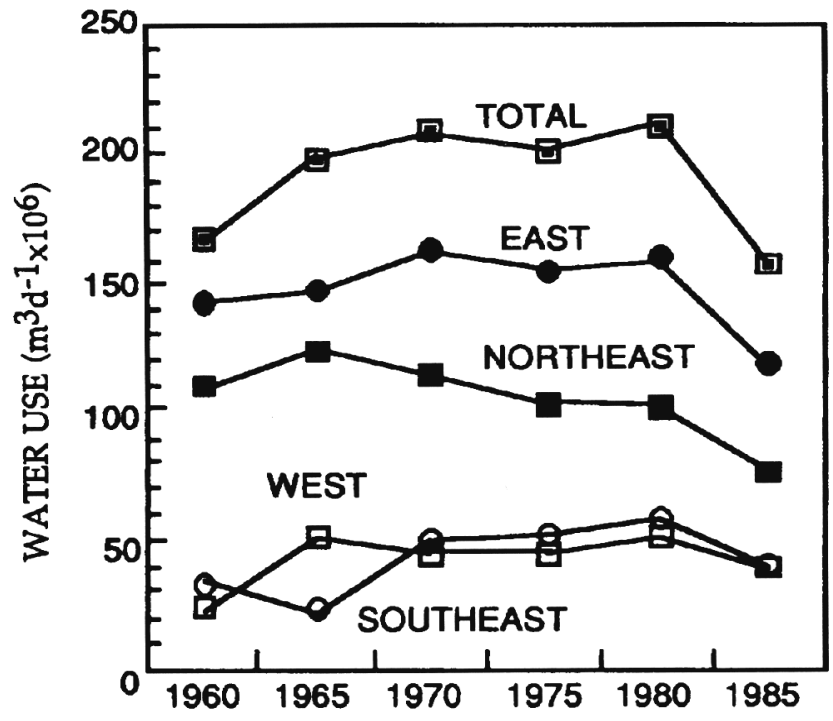

Fig. 5. Trends in regional industrial water use, 1960-85. 
million $\left.\mathrm{m}^{3} \cdot \mathrm{day}^{-1}\right)$. This $13 \%$ decline was the first decline since recordkeeping began (Fig. 4). The rate of increase in water withdrawal has been declining since 1965-70. The 1985 estimates were less than the 1980 estimates, because the industrial sector used less electricity and power plants used more cooling towers. The 5-year decline in withdrawals for thermoelectric-power generation in the Northeast $(13 \%)$ and Southeast $(25 \%)$ are in sharp contrast to the West, where withdrawals increased 28\%. In the West during 1985, $>50 \%$ of the water used to generate thermoelectric power was saline, which contains $>1000 \mathrm{mg}$ dissolved solids/liter.

\section{Industrial water use}

Total industrial water use (which, in this paper, includes mining and commercial water uses) has fluctuated from 1960 to 1985 , with the largest decline occurring from 1980 to 1985 (Fig. 5). Total industrial water use in 1985 was $\approx 159$ million $\mathrm{m}^{3} \cdot$ day $^{-1}-25 \%$ less than the maximum use reported (212 million $\mathrm{m}^{3} \cdot$ day $^{-1}$ in 1980) and 5\% less than the 167 million $\mathrm{m}^{3} \cdot$ day $^{-1}$ reported in 1960 . All regions reported less industrial water use during 1985 than during 1980. Industrial water use declined due to improved plant efficiency, new technologies that require less water, and an economic slowdown that probably decreased the need for industrial water.

\section{Future trends}

Water use in the domestic sector likely will increase as population increases. However, higher water prices and active water conservation programs may reduce the per-capita use rate. Increased competition for instream water uses, such as river-based recreation, aesthetic enjoyment, fish and wildlife habitat, and hydroelectric power, in addition to higher municipal uses make it almost economically impossible for irrigation agriculture to compete for available water. A leveling of agricultural water use combined with increasing population and urbanization suggests that, for the foreseeable future, new balances will have to be struck between rural and urban water use, especially in the West (Carr et al., 1990). It seems likely that industrial water use and use per unit of production will continue to decline in most sectors, although probably not as sharply as it has recently (Carr et al., 1990).

Experts on western water supplies agree that the West is in transition from an era of water development to one of water management and conservation (see Wilkinson, 1985). Current and future attention will focus on using existing surface-water projects rather than on developing large storage reservoirs and major aqueducts, more efficient water application techniques, and other water conservation measures, such as lining irrigation canals and installing more efficient plumbing fixtures in homes and office buildings.

\section{Literature Cited}

Can, J.E., E.B. Chase, R.W. Paulson, and D.W. Moody. 1990. National water summary 1987. U.S. Geological Survey Water-supply Paper 2350.

Solley, W.B., C.F. Merk, and R.R. Pierce. 1988. Estimated use of water in the United States in 1985. U.S. Geological Survey Circ. 1004.

Wilkinson, C.F. 1985. Western water law in transition. Univ. of Colorado, Boulder, Law Rev. 56:317-345. 